\title{
Media Reports on China's Economy: A Critical Discourse Analysis
}

\author{
Sue Wang ${ }^{1}$ \\ ${ }^{1}$ School of Foreign Studies, Central University of Finance and Economics, Beijing, China \\ Correspondence: Sue Wang, School of Foreign Studies, Central University of Finance and Economics, 39 South \\ College Road, Haidian District, Beijing, China. E-mail: suewangcufe@126.com
}

Received: October 2, 2019 Accepted: November 2, 2019 Online Published: November 14, 2019

doi:10.5539/ells.v9n4p45 URL: https://doi.org/10.5539/ells.v9n4p45

\begin{abstract}
Today, the news reports by the mainstream media in Britain and the United States play an important role in the international arena. As a research area of critical discourse analysis, news discourse has attracted much attention. This study selected research materials from a series of reports by The Economist, a well-known international business and finance magazine, on China's economic development. The appraisal theory and its three subsystems are used as the analysis framework. The study explores the discourse resource choices and the characteristics of the magazine's evaluation resources in its economic reports on China. By analyzing and understanding the evaluation resources of foreign media on China's economy reports, the study attempts to demonstrate the implicit messages behind the discourse resources so as to help the readers better understand the evaluation of foreign media on China's economy, and analyze the channels for their realization, so as to improve readers' critical reading ability.
\end{abstract}

Key words: critical discourse analysis, appraisal theory, news analysis

\section{Introduction}

\subsection{Critical Discourse Analysis}

Critical discourse analysis (CDA) was first proposed by Fairclough, a British sociolinguist, who defined discourse as the use of language as a social practice. It emphasizes the analysis from three aspects: text, discourse practice and social practice (Liu, 2008). The framework of CDA is Marxist theory, which includes language, ideology and power. Fairclough stressed that discourse is not only shaped by society, but also can be used to construct social realities, thus highlighting the role of discourse in social change. He also pointed out that the same phenomenon could be described in quite different discourses which could further construct social realities and therefore proposed critical language awareness (Fairclough, 2003).

CDA was developed by other scholars such as Van Dijk who introduced social cognitive approach into discourse analysis, emphasizing the interaction among cognition, discourse and society. He investigated stereotypes, the persistence of racial prejudice and the abuse of power by the ruling elite. He believes that cognition, as a collective identity of society, connects social structure with discourse structure (van Dijk, Aertselaer, \& Potz, 2004). Individual social cognition is influenced by the collective concepts and customs of society, many of which are inherited through discourse. He suggested analyzing the macro-structure of semantics, the form of the whole discourse and part of discourse, the specific form of language realization and context. Another scholar Wodak proposed a discourse-history analysis method, emphasizing that the social and historical background of discourse practice should be comprehensively examined from the macro-social, political and textual contexts, and how power-holders maintain their dominant position by using language and other symbolic practices (Reisigl \& Wodak, 2001). This school originated from sociolinguistics and anthropology, influenced by Habermas' concept of public sphere. Its core is to combine text analysis with context analysis (Liang, 2013). One of the advantages of this method is that it emphasizes the influence of social, historical and political background factors (Wodak \& Meyer, 2009), but there is still a lack of specific and systematic analysis method.

\subsection{Halliday's Systemic Functional Linguistics and Martin's Appraisal Theory}

Another important branch of CDA uses Halliday's systemic functional linguistics as its research analysis framework. Halliday's views on a series of theoretical issues, such as the nature of language, language system, language function, language structure, the relationship between language and context, cohesion and coherence, have had a profound impact on the development of discourse analysis (Zhu, 2003). Systemic Functional 
Grammar (SFG), as an analytical tool, interprets the ideological meaning behind language structure by observing language characteristics and its historical background, and reveals the relationship among language, power and ideology. The appraisal theory proposed by Martin and others is the inheritance and development of Halliday's SFG (Martin \& White, 2005). Halliday's SFG includes three meta-functions: conceptual function, interpersonal function and textual function. Appraisal theory breaks the limitations of the previous analysis of interpersonal function and provides a useful tool to analyze the evaluation resources in interpersonal interactions. The appraisal theory can be divided into three subsystems: attitude system, engagement system and gradation system. In other words, the appraisal theory mainly studies the following three questions: (1) How do the speakers/authors feel? (2) How are these feelings expressed? (3) How do the listeners/readers participate in the dialogue process through discourse? The three subsystems of the appraisal theory: attitude, engagement and gradation are able to provide answers to these three questions. Attitude system refers to all positive or negative feelings and opinions, including affect, judgment and appreciation, which express feelings and evaluate behaviors of the speakers or writers. Engagement system refers to the way people express their attitudes, which can be expressed directly or indirectly, namely, in what Martin called "monoglossic" and "heteroglossic". The gradation system classifies attitudinal resources, including force and focus. Force refers to the strength and magnitude of evaluation resources and is divided into strong (raise) and weak (lower); focus refers to the typicality and accuracy of evaluation resources, and could be further divided into two categories: obvious (sharpen) and fuzzy (soften). Since it was put forward by Martin and others, the appraisal theory has attracted great attention of researchers in linguistic circles who have applied it to interpersonal function analysis in various discourses (Fu, 2016).

\subsection{The Economist's Reports on Chinese Economy}

With the development of critical discourse analysis, news discourse, as an important research field of critical discourse analysis, has attracted more and more attention. Nowadays, the mass media with English as its medium has an increasing influence in the international arena. However, news reports could never be absolutely impartial even they claim to be so. Many news texts seem impartial, but actually they express various ideological meanings explicitly and implicitly, which exerts a subtle influence on readers.

The mainstream reports by the financial and economic media in the United Kingdom and the United States dominate the international access to financial information. And how do these countries report on China's economic development? We need to understand these news texts through scientific analysis and research, and hope to help the readers both in and outside China to better understand these English media coverages.

Founded in 1843, The Economist focuses on political and economic news and emphasizes the use of facts and being objective in its stand. The articles published are not usually credited to some particular individual authors, but being presented as a collective work by the editors of the weekly magazine. The magazine established a Chinese column in 2012, a special column for a third country after the United Kingdom and the United States.

The existing literature has conducted critical discourse analysis of news (such as Dong \& Wang, 2012; Li, 2016; Wei, 2014) but these are analyses of the news in general (Shao \& Hui, 2016) or political news (Cao \& Zhao, 2019; Jiao \& Liu, 2019), and there is few specific studies on economic reports from the critical discourse perspective ( $\mathrm{Li}, 2018)$. The ideology contained in the discourse is also rarely involved (Chen, 2011). Through appraisal theory framework, we can understand the evaluation resources of foreign media on China's economic reports, gain an in-depth understanding of foreign media's evaluation of China, and analyze the channels of its realization to improve readers' critical reading ability.

The study hopes to answer the following questions: 1) What are the lexical and grammatical resources used by The Economist, one of the mainstream English media in their economic reports on China? What ideological factors are behind these lexical and grammatical resources? 2) How do the reports distribute the evaluation resources when presenting China's economy? What are the characteristics of the evaluation resources in the three subsystems? In theory, this study can enrich the theoretical construction of functional linguistics, especially appraisal theory and critical discourse analysis. From the practical level, it can help readers to read more critically about the news reports and improve the readers' critical reading abilities.

\section{Method}

\subsection{Data Collection}

The data used for this study are selected from The Economist (September 12th, 2015) in which there is a series of special reports titled "Business in China". These reports consist of nine parts covering topics such as private firms, entrepreneurship and technology, innovation, consumers, manufacturing, foreign investment and reform. 
Compared to the majority of The Economist articles which are known for their brevity, these reports provide a more substantial sample of its analysis of Chinese economy.

\subsection{Research Tool}

This study used UAM Corpus Tool as the analysis software. The software is developed on the basis of systemic functional linguistics and can be used for discourse analysis. Moreover, the software provides automatic function so it is possible to encode and analyze the corpus automatically, but it could also perform manual coding analysis according to the requirements of researchers, and the built-in program can automatically record the result of manual coding and generate the research result, which can be effective since it improves efficiency and the credibility of research.

This study built a small corpus with the special reports which has about 12,909 words in total. The appraisal theory and its three subsystems are used as the framework for analysis. The study analyzed the self-built corpus from the attitudes, engagement and gradation distribution and characteristics of the three subsystems to explore the characteristics of the appraisal resources of the magazine's report on China's economy.

\subsection{Coding Sheme}

The coding scheme is manually built by the author into the UAM corpus tool. The coding focused on the appraisal resources used in the reports. The division of the appraisal resources is based on the three aspects: attitude, engagement and graduation. Under each category, there are also some subcategories. Examples are given as to what would be considered as corresponding resources in the following Table 1.

Table 1. Coding scheme for the appraisal resources in the report

\begin{tabular}{|c|c|c|}
\hline & & examples \\
\hline \multirow[t]{7}{*}{ attitude } & affect & In particular, the decision in 2012 by a committee of America's Congress to blacklist Huawei and \\
\hline & & ZTE, another big Chinese telecoms firm, on national-security grounds was shameless \\
\hline & & techno-nationalism. \\
\hline & & Chinese firms are getting fed up with paying licensing fees and royalties to foreigners. \\
\hline & judgement & $\begin{array}{l}\text { BGI, a privately run research outfit, is one of the world's most highly regarded genomics institutes. } \\
\text {...the private sector is full of young dragons exposed to the Schumpeterian forces of creative } \\
\text { destruction. }\end{array}$ \\
\hline & appreciation & Huawei, for instance, has emerged as a world-class telecoms-equipment firm \\
\hline & & Thomson Reuters, a research firm, claims that China is an "undisputed patent leader". \\
\hline \multirow[t]{2}{*}{ engagement } & monoglossic & China has a long history of invention. \\
\hline & heteroglossic & William Kirby of Harvard University and his co-authors observe that... \\
\hline \multirow[t]{2}{*}{ graduation } & force & $\begin{array}{l}\text { They are delivering not only ever better manufactured goods but also increasingly sophisticated } \\
\text { high-tech-based services. }\end{array}$ \\
\hline & focus & Growth maybe sagging, but ... \\
\hline
\end{tabular}

\section{Findings}

\subsection{What Is Being Said About China's Economy: The Positive and Negative}

It is found that The Economist was optimistic in general towards Chinese economy in the reports although it did point out the problems about the prospects of Chinese economy. In the following two examples, we see that they gave very positive evaluations about China's economic prospects.

\section{Example 1}

Despite China's recent troubles, the prospects for its entrepreneurial private sector remain bright, says Vijay Vaitheeswaran.

Example 2

As long as the government does not interfere too much, there is every reason to think that they can help deliver the required growth and turn the Middle Kingdom into the world's largest and most dynamic economy.

The description such as "bright" and "there is every reason to think" indicated that the report was very confident about China's future. The superlatives such as "the world's largest and most dynamic" were also used, which showed that the authors were inclined to vote for the future of China's economy. Of course, they are using some conditions such as "despite China's recent troubles" and "as long as the government does not interfere too much" 
to make their argument more balanced.

Besides these general positive appraisals of China's future, The Economist showed distinctively different opinions towards the state-owned enterprises and private sectors in China. It clearly stated its evaluation of the former and the Chinese government in the negative and critical tones.

Example 3

China's leaders need to stop coddling bloated state enterprises... President Xi Jinping's government has acknowledged that this model (state planning and heavy investments in infrastructure and property) has run out of steam

\section{Example 4}

$\underline{\text { Reluctantly, they are beginning to accept that their top-down approach may not be up to the challenges }}$ ahead.

These descriptors such as "bloated", "run out of steam" and "not up to the challenges" are very clear opinions of the authors towards the government's role in economy and the state-owned enterprises. In contrast with that, it is very clear that The Economist was greatly in favor of the private sectors in the Chinese economy and these private businesses were highly applauded by The Economist.

Example 5

The spectacular rise of China's private sector can be seen as a renaissance.

Example 6

This report will argue that private firms have been responsible for the vast bulk of modern China's economic advance.

Example 7

They are agents of change, risk-takers and, these days, true innovators that take full advantage of the potential of new technology.

Example 8

They are delivering not only ever better manufactured goods but also increasingly sophisticated high-tech-based services.

The report made its stance very clear by criticizing the state-owned enterprises for their low efficiency yet was greatly generous in their positive affirmations about the contributions that private sectors made to the development of Chinese economy. We could see this message from words such as "spectacular", "agents of change, risk-takers, true innovators" to describe the private enterprises in China. These descriptions are very strong evidence of the authors' positive attitude. When reading through the report, it is demonstrated explicitly that the authors were applauding for the private sectors profusely.

Example 9

Private farmers, rural enterprises and small urban entrepreneurs did more from the fringes to advance the economy than did central planners in Beijing.

Example 10

There is every reason to think that they can help deliver the required growth and turn the Middle Kingdom into the world's largest and most dynamic economy.

\subsection{How It Is Being Said About China's Economy: The Appraisal Resources}

If the above presented general descriptions and general impressions of the reports' evaluation, in the following, we are going to see in more detail about how the reports showed their stand through these various appraisal resources. That is, we are going to see how the reports expressed their attitude through the different appraisal resources and what the messages are with these appraisal resources. Through the coding of UAM tool, it is found that the authors used different appraisal types including attitude, engagement and graduation to build a discourse over China's economy. Altogether, in the reports, about 132 appraisal resources are found, with attitude resources roughly $33 \%$, engagement resources, $40 \%$ and graduation resources, $27 \%$. 
Table 2. Different appraisal resources distribution

\begin{tabular}{lll}
\hline APPRAISAL-TYPE & $\mathrm{N}=132$ & \\
\hline attitude & 43 & $33 \%$ \\
engagement & 53 & $40 \%$ \\
graduation & 36 & $27 \%$ \\
\hline
\end{tabular}

\subsubsection{Attitude Resources}

The attitude resources could be further divided into three subsystems including affect, judgement and appreciation. Affect under this system refers to words or expressions such as "sad", "upset", "dislike". It could be behavioral or mental activity. It is very interesting that the reports used only a very small number of affect resources, indicating that the authors might think affect is not the best way to show ones' attitude. In comparison, it could be seen that the reports used large number of judgment resources to show their stance. Judgement could be further divided into social esteem and social sanction (Halliday, 1994). The former would include elements such as normality - whether someone (or something) is distinctively from others, capacity — whether someone is powerful and tenacity - whether someone is resolute. The latter would include veracity - whether someone is honest and propriety — whether someone is moral or not. Here it is only reported under the category of judgment.

Table 3. Attitude resources distribution

\begin{tabular}{lll}
\hline ATTITUDE-TYPE & $\mathrm{N}=43$ & \\
\hline affect & 6 & $5 \%$ \\
Judgement & 32 & $24 \%$ \\
Appreciation & 5 & $4 \%$ \\
\hline
\end{tabular}

\section{Example 11}

China's clumsy devaluation in August

SOEs have grown inefficient and indebted

But these lumbering giants are not the drivers of China's economy; they are millstones around its neck.

In this attitude subsystem, the reports used both lexical and grammatical resources to express its attitude towards China' economy. The use of judgement resources helps to deliver the reports' stance on the economy as a mixed picture: while the state-owned enterprises were doing badly, the private sectors were making a great contribution to the economic development in China.

\subsubsection{Engagement Resources}

Under the engagement appraisal resources, there are two kinds of subdivisions. The first one is monoglossic, which means the stance would be directly stated and no other voices and opinions quoted. For instance, monoglossic engagement resources were used in the following examples.

Example 12

A century ago Shanghai was a cosmopolitan city bursting with entrepreneurial energy.

China has a long history of invention.

Up to now, China's leaders have relied on state planning and heavy investments in infrastructure and property.

The second type of engagement is the heteroglossic which means the authors' stance might be indirectly vocalized through some other channels, usually in line with the authors' opinions.

Example 13

The seamstresses think their work is better and safer than ...

Doomsters are already predicting a long period of stagnation...

McKinsey, a consultancy, estimates that...

John Rice, the vice-chairman of GE, accepts that...

The late Ronald Coase, a Nobel prize-winning economist, noted in a paper... 


\section{David Ahlstrom of the Chinese University of Hong Kong points out...}

William Kirby of Harvard University and his co-authors observe that...

Table 4. Engagement resources distribution

\begin{tabular}{lll}
\hline ENGAGEMENT-TYPE & $\mathrm{N}=53$ & \\
\hline monoglossic & 16 & $12 \%$ \\
heteroglossic & 37 & $28 \%$ \\
\hline
\end{tabular}

In the reports, the authors used both monoglossic and heteroglossic resources to present their own voices or opinions towards the Chinese economy. It could be seen that in the reports, more heteroglossic resources are employed. Compared with monoglossic where the stance was stated explicitly, the heteroglossic relied on another party to express their opinions. However, the reports appeared to be more objective by quoting others' stance and hence implicitly expressed their own stance. In the above examples, the insiders or the authoritative figures' opinions were frequently used to deliver the more objective effects of evaluation.

\subsubsection{Graduation Resources}

Graduation resources are subdivided into two categories: force and focus. The first category refers to resources used by the authors who raise or lower the interpersonal impact, force or volume of their utterances. The second refers to the resources used by the authors to blur or sharpen the focus of their semantic categorizations. It is found the reports used a large number of the first-category resources to serve its purpose of the appraisal of Chinese economy.

Table 5. Graduation resources distribution

\begin{tabular}{lll}
\hline GRADUATION-TYPE & $\mathrm{N}=36$ & \\
\hline force & 31 & $23 \%$ \\
focus & 5 & $4 \%$ \\
\hline
\end{tabular}

Example 14

Perhaps, but there may be another explanation.

The bloated state-owned sector must be reformed so that private firms can compete on equal terms.

It seems likely to lead to a massive spending binge, but companies should remain wary.

Graduation resources work as a way to carefully manage the expressions of attitude or engagement to take into account of the possible challenges or contradictions from those who have different views. In some cases, the softening of the tone or the force would make the argument easier to be accepted. In other cases, the sharpening or increased emphasis would further stress the authors' explicit stance.

\section{Conclusion}

Discourses not only provide information about the speakers or writers' attitude but they also have the function of reshaping, constructing and even changing society. It could establish interpersonal relationships and establish the system of knowledge and beliefs. In other words, discourses are not only discourses, they continued their existence along the use in the conversations into realities and build new realities.

This study used the appraisal framework, a particular approach to exploring, describing and explaining the way language is used to evaluate, to adopt stances, to construct textual personas and to manage interpersonal positioning and relationships. In this study, it is found that the authors of the reports pass judgements on people generally and form alliances with those who share their views and distance themselves from those who do not. The reports offer their comments on China's economic development by evaluating the contributions from different sectors of the economy including the state-owned enterprises and private enterprises. The means of evaluation include attitude system, engagement system and graduation system. Among them, judgment resources are more often used in the attitude system, and heteroglossic system are more often used in the engagement system, which helps to create a neutral or objective stance.

The reports' evaluation is aimed at economic development, but at the same time, it also implies political and ideological concepts. While the reports acknowledged that it is difficult to draw a clear distinction between the 
state-owned enterprises and private ones, they still showed a very negative attitude towards the former while applauding the private sectors. It might be true that the authors used a variety of resources to present their evaluation and tried to demonstrate their objectivity by using more neutral or what seemed to be objective resources, yet frequently the author's stance were more implicitly presented through the variety of appraisal resources used. Using critical discourse theories, this stance not only simply describes what exists, it described more accurately what the authors saw as being present and they used discourses to present their views on these issues. As a step further, the discourse they created not only stay as mere discourses. As the reports being read, they might also become part of the reality of the readers and they could also bring changes to people's attitude and even further, they might bring social changes as well. In reading this kind of economic articles, therefore, readers should deeply analyze the author's implicit intentions and improve their critical reading consciousness so that they could understand the economic texts containing political and ideological contents in a more comprehensive manner.

\section{References}

Cao, W., \& Zhao, Y. (2019). The image of China in mainstream Argentina media: A critical discourse analysis of the $19^{\text {th }}$ CPC National Congress. Journal of Xi'an International Studies University, 27(3), 37-42.

Chen, Q. (2011). Corpus-based discourse and ideological analysis: a case study of routine press conferences between China and the United States. Journal of Changchun University of Technology, 4, 56-59, 72.

Dong, Y., \& Wang, J. (2012). Critical discourse analysis of English news. Journal of Hubei University (Philosophy and Social Sciences Edition), 39(2), 133-136.

Fairclough, N. (2003). Analysing Discourse: Textual Analysis for Social Research. London and New York: Routledge. https://doi.org/10.4324/9780203697078

Fu, Y. (2016) Appraisal System: Theories and Practices. Xiamen: Xiamen University Press.

Halliday, M. A. K. (1994). An Introduction to Functional Grammar. London: Edward Arnold.

Jiao, J., \& Liu, M. (2019). The construction of Confucius Institute and Chinese culture from the British and American media: A critical discourse analysis of news reports in the Guardian and the New York Times. Journal of Tianjin Foreign Studies University, 26(4), 13-23.

Li, J. (2018). A Corpus-assisted analysis of discursive construction of China's economy in the UK Press. Foreign Language Research, 3, 52-57.

Li, X. (2016). A Corpus-based Study of English Newspapers' Editorial Attitudes. Contemporary Foreign Language Studies, 6, 47-53.

Liang, S. (2013). Discourse Studies in Different Foreign Language Regions. Hubei Social Sciences, 5, 138-140.

Liu, L. (2008). Review of Critical Discourse Analysis. Journal of Foreign Languages, 3, 102-109.

Martin, J. R., \& White, E. R. R. (2005). The Language of Evaluation: Appraisal in English. New York: Palgrave Macmillan.

Reisigl, M., \& Wodak, R. (2001). Discourse and Discrimination: Rhetorics of Racism and Anti-Semitism. London and New York: Routledge.

Shao, B., \& Hui, Z. (2016). The "Chinese Dream" in the Perspective of Western Media: A Corpus-based Critical Discourse Analysis. Foreign Languages Research, 6, 28-35.

van Dijk, T. A., Aertselaer, J., \& Potz, M. (2004). Introduction: Language, Discourse and Ideology. In M. Putz, J. Aertselaer \& T. A. van Dijk (Eds.), Communicating Ideologies: Multidisciplinary Perspectives on Language, Discourse, and Social practice. Peterlang.

Wei, Z. (2014). Interpretation and Translation Strategies of English News Discourse: Critical Discourse Analysis Based on Conflict News Report in South China Sea. Journal of Chongqing University of Technology: Social Sciences, 12, 127-133.

Wodak, R., \& Meyer, M. (2009). Methods of Critical Discourse Analysis. Sage Publications.

Zhu, Y. (2003). Fifty years of discourse analysis. Journal of Foreign Languages, 145, 43-50. 


\section{Copyrights}

Copyright for this article is retained by the author, with first publication rights granted to the journal.

This is an open-access article distributed under the terms and conditions of the Creative Commons Attribution license (http://creativecommons.org/licenses/by/4.0/). 